\title{
Multi-Dimensional Approach To Crisis Management In The Church
}

\author{
George O. Folarin, PhD \\ Adewale J. Adelakun, PhD
}

Department of Religious Studies, Obafemi Awolowo University

Ile-Ife, Osun State, Nigeria

doi: 10.19044/esj.2016.v12n23p270 URL:http://dx.doi.org/10.19044/esj.2016.v12n23p270

\begin{abstract}
The church, like every other society, encounters internal crisis. Theological Seminaries and Universities are well-positioned to help the church in its search for methods of coping with the problem. But because the studies of religion and other disciplines in many Universities are academic, supposedly objective, and comparative, products of the research findings from Universities with interest in religion and social sciences can contribute to the search for multidimensional management of church crisis. Eclectic theory of civil conflict resolution of Keih as modified for religious conflict management by Israel Akanji was applied to the data collected for this work.
\end{abstract}

Keywords: Conflict; crisis; Christian leadership; vision; problem-solving approach; and metacommunication

\section{Introduction}

There have been many researches on managing church conflicts but all of them either focus on the causes or the use of the Bible in managing the conflicts. In Nigeria for example, Oluseye D. Oyeniyi (2014) examined the theological basis and principles of church reconciliation in Matthew 18:1535, while George O. Folarin, Adewale J. Adelakun, and Comfort O. Folarin (2015) applied the principles of conflict resolution in Luke to church problem in Nigeria. In the United States of America, the empirical work of Kay L. Peters (2010) concluded that conflict in the church is common, normal, neutral and could be delightful, but that many pastors are not managing it well, and that many Seminaries are not properly addressing the issue of conflict management training (pp. 48, 49). In another empirical research work in the USA, this time on the study of the conflicts that have led to the termination of many Southern Baptist Convention (SBC) pastors, Donald Q. Hicks (2010) concluded that the SBC, as in 2010, had no ministry 
in place to address the problems of its pastors who are casualties of church conflicts. In a new dimension, a survey carried out by Christianity Today (2016) ranked doctrinal and cultural factors low as causes of church conflict. Eighty five percent (85\%) of the research subjects viewed leadership struggle/fight for control as the primary cause of church conflict ("Leadership Surveys Church Conflict", 2004). The issue of leadership method or style has a lot to gain from many researches carried out in social sciences on group dynamics. No researcher has, to the knowledge of the current writers, explicitly applied multidisciplinary approach to the problem of church conflict despite the fact that many church counsellors and pastors study psychology and sociology in renown institutions in addition to their theological and pastoral training. Although Jay E. Adams was confrontational to the use of psychology and even regarded its use in Christian counselling as devilish, he had a degree in psychology. Narramore is more supportive of combining psychology with theology in Christian counselling. He also has degrees in psychology, education, business administration and music from Arizona State University, University of Southern California and Columbia University respectively. The current work attempts to fill the existing lacuna by suggesting a working model that combines the best insights from the social sciences with theology on approaching the problem of church conflict from a multidisciplinary perspective.

While crisis is inevitable, it can be properly managed. Often however, church crisis is poorly addressed by ignoring vital dynamics. Although Adams' criticisms of making use of psychological and sociological insights in dealing with church conflict are noted, they can be rightly avoided. In his book, Competent to Counsel, Adams (1986, pp. xi-xxii) alleges that social sciences often underplay sin as the cause of conflict or even sometimes deny the existence or effect of sin in conflict, and that sciences absolve the guilty of responsibility, but one does not need to be as extreme as Adams insinuated. Adams' extreme view is well critiqued in the article, Psychology is the Devil: A Critique of Adams' Counseling Paradigm (2007). Barbara Roberts (2012) raises objection to Nouthetic counselling of Adams by saying that it "is not appropriate for abusive victims in our opinion. In fact, we think it isn't appropriate in most any case” (Psychology is the Devil, 2007; Roberts, 2012). The basic assumption of this work is that the causes of church crisis are multidimensional. If that is the case, then church crisis would need to be approached multi-dimensionally. At least three points are germane to this discussion: the church has its share of conflict; if properly handled, conflict may be positive; and managing church conflict is better with multidimensional approach. This article focuses on 
applying multidisciplinary approaches to the management of conflict in the church while still admitting the primacy of religious factors.

Klay Kieh, Jr. (“Theories of Conflict Resolution”, 2002, p. 12) proposes eclectic theory to address conflicts. Although his work is not on church conflict, his work is relevant to the church in that it acknowledges that conflicts are caused by multiple factors. Keih's theory particularly identifies political, social, economic, historical, cultural and psychological factors as responsible for conflict but to varying combinations. Israel Akanji (2011, p. 65) broadens Keih's theory to include religious factors since the theory as originally presented by Keih was incapable of adequately addressing religious conflict. The current research effort proceeds with the assumption that while church conflict primarily needs religious solutions, it will benefit greatly from the secondary contributions of social sciences.

\section{Theological Basis for Multi-Disciplinary Management of Church Crisis}

The created world is not only a witness to the existence of God, it also reveals God's relationship with and work through it. Whenever scientists "discover" any truth or fact earlier unknown in nature, theistic scientists hold that such belongs to God. That “all truth is God's truth” has therefore almost attained the status of a truism among most Christian scholars. "All truth” by implication, cannot be less than “all.” St. Augustine of Hippo drew the attention of other theologians to this point. St. Thomas Aquinas supported the statement, and the Reformers popularized it (Mathison, 2011). In his book, On Christian Doctrine, Augustine argues, "let every good and true Christian understand that wherever truth may be found, it belongs to his Master [God].” Adopting this theological position, John Calvin comments, "All truth is from God; and consequently, if [even] wicked men have said anything that is true and just, we ought not to reject it; for it has come from God" (Calvin, n.d.). While the Reformers and the Evangelicals have understandably accepted this position, not all of them, till date, accept its full implication. Mathison (2011) explains how the Reformed Church conceives of this theological position,

[...] if something is true, it is because it ... has been revealed by God, or because it is an accurate understanding of the nature of something created by God, or because it is an accurate description of something decreed by God. In other words, a God-centered view of truth demands that we affirm that all truth is God's truth. That which is true is true because God said it, created it, or decreed it.

Many biblical scholars concur that such truth includes natural scientific truth. That all truth is God's does not mean that every interpretation of a discovered truth from whatever source is correct. When there is conflict in truth claim between the Bible and natural science, it is 
most likely because either the Bible scholar, the scientist, or both misinterpret the evidence. A major implication of this theological position is, "when Scripture is properly interpreted and God's creation is properly interpreted, there will be no contradiction. ... If scientists discover something about God's creation that is actually true, it will not and cannot ultimately contradict the Scriptures when they are properly interpreted" (Mathison, "When Science and Scripture Conflict", 2012). Some other Christian psychologists who support the integration of psychological with theological truth include Bill White, James Dobson, Larry Crabb, and John Coe. There are, however, Christian scholars who argue otherwise (Flashing, 2011). They argue that natural science is not related to general revelation, that general revelation is only about God, and that the sin-depraved man cannot properly understand God's revelation in nature (Psalms 19:1-4 cf. Rom 1:18, 21-23, 28). While it is legitimate to argue that the truth from general revelation through the sciences is non-salvific, it is sound to affirm that such truth is complementary to the truth from the special/specific revelation which is salvific. Of course, it is convincing that natural truth can only be rightly understood through the spectacles of faith. R.C. Sproul is extreme in the extent to which he supports the complementarity of the truth of science and biblical revelation, and has been harshly criticized as a heretic for his view ("R.C. Sproul Responds", n.d.). He is convincing however that "while science cannot overturn an actual teaching of Scripture, it can sometimes correct a misinterpretation of Scripture" (Mathison, "Interpreting General and Special Revelation”, 2012). The hostility of Bernard Ramm (1967, p. 25) and Andrew S. Kulikovsky ("Scripture and General Revelation”, n.d.) to the truth of science leads them to warn Christian scholars against employing social scientific findings in their ministerial work. More Christian scholars however hold that Ramm and Kulikovsky exaggerate the danger of science unfairly. The current research approaches the issue of multidisciplinary management of church crisis from the perspective that the church comprises humans who are psychosomatic and so need both social scientific and spiritual-theological helps.

\section{Resolving Terminological Crisis}

The Christian Leadership Centre of the Andrews University defines "Christian leadership” as “... a dynamic relational process in which people, under the influence of the Holy Spirit, partner to achieve a common goal" ("Defining Christian Leadership"). This definition is persuasive to the present writers and is adopted for this work. Dobbins (1968, p. 18) cautions that dominance, superiority, command, and control are not foreign to Christian leadership. 
The church is characterized by both human and spiritual attributes ("Church Management: Combining the Spiritual and the Organizational”). Church management, therefore, involves blending the spiritual and the human in the ecclesia (church). It is in the human relational aspect that social sciences and humanities hold the prospect of collaborating with the church in the search for managing its crisis.

In a way, "conflict" is "... a disagreement through which the parties involved perceive a threat to their needs, interests or concerns" (“About Conflict”). This definition raises four important issues: It is a disagreement; parties are involved; threat is perceived; and needs, interests, or concerns are involved. Similar issues have led some others to view "conflict" as exclusively implying "... the imagination of painful memories of arguments, hurt feelings, violence, and hatred” (McSwain \& Treadwell, 1981). But conflict does not need to always be so ("Conflict Management: Psychology and Science". The more important thing is not the conflict itself but how it is handled. Pearce (n.d.) differentiates disagreement from conflict thus,

When you disagree with someone, you have a difference of opinion because you and the other person have different interests, values, needs and intentions. Disagreeing with someone isn't a bad thing. It can be viewed as positive and functional as well as natural. Disagreement doesn't have to lead to a huge fight. Conflict, on the other hand, is a powerful collision or dispute of needs, values, interests and intentions between two individuals or communities, groups, nations and organizations.

Conflict is generally “... considered unhealthy competition ... [which] includes distrust, hostility, lack or loss of affinity and suspicion. Conflict happens when needs aren't met or when a group or a person is seen as obstructing the goals of another group or person" (Pearce). But while its outcome is often negative, it can sometimes be constructive, lead to purposeful disagreement and even result in better decision making. So the way conflict is managed in the church is very important.

\section{Contributions of Social Sciences}

At least three books that are "psychological" have made significant impact on many Christian youths. These are Transformed Temperaments (LaHaye, 1971), Your Temperament: Discover Its Potential (LaHaye, 1984), and Spirit Controlled Temperament (LaHaye, 1991). They are all written by the same author, Tim LaHaye, and published by a celebrated Evangelical publishing company, the Tyndale Press. The books are written in simple English, they provide simplistic explanations to life's ever increasing complexities, they give simple answers to humans understanding of 
themselves and others, and they appeal to the populace. The fact that Tyndale House publishes the books adds to the acceptability of the books especially among the Evangelicals. Several missionary training institutions that use the books as textbooks boost their popularity. For example, Bob Barrows, a lecturer in ECWA Theological Seminary, Igbaja, Nigeria, did recommend one of the books in "Psychology of Religion” class in 1982.

LaHaye is not a psychologist as he wants readers to believe. Rather, he is a trained pastor who adapts for pastoral use an old psychological theory (Yurica, 2007). Understandably, his integrity has been questioned by some psychologists and his position has even been described by several people as "pseudo-psychological” (“Tim and Beverly LaHaye Exposed”, n.d.). There are however psychologists who affirm the helpfulness of temperamental study. They include Mary K. Rothbart, Stephen A. Ahadi, and David E. Evans (2000, pp. 122-135). If only LaHaye had acknowledged that he is not a psychologist, and that he only builds on the findings of certain psychologists, the criticisms of his works would have been less severe. The very fact that LaHaye's books are criticised may, in itself, be an evidence to the impact of the works. The current researchers have heard from several pastors how the use of LaHaye's books on temperaments have doused tensions and improved relationships within several ecclesiastic communities.

Theories of conflict are varied and multiple (Meier, Minirth \& Wichern, 1982, pp. 299-306). Akanji (2011, pp. 59-64) broadly classifies them into three: Inherency (Micro), Contingency (Macro) and, Eclectic (Hybrid). To some theorists, conflict is inherent in man. The greatest theorist of Inherency is Sigmund Freud. To some others, aggression and its various forms of manifestations are not innate but dependent upon external factors. Contingency theories focus on the role of groups in conflict. The most popular Contingency theorist is Karl Max. The church generally abhors Freud and Max for their extremity but there is a measure of truth in their positions. Eclectic theorists, on the other hand, argue that conflicts are products of multiple factors which could be inherent and contingent. A single variable will therefore not likely be able to fully explain the cause of conflict. This is an interesting insight from the social sciences. Interpreted in the context of church conflict, causes of all crises cannot be reduced to sin. Experience has shown that there are committed Christians who are entangled in church conflicts.

According to Freud, the role of a crisis manager is to attempt to uncover the subconscious conflicts in persons. Freud points out that there are certain instincts in humans that could be "[...] destructive and when administered towards others, is expressed in aggression which may turn harmful” (Akanji, 2011, 59). Alfred Adler (1870-1937) is however of the view that conflict results from people's self-defeating inferiority feelings 
which often sets in when there is discrepancy between self and ideal-self convictions ("Alfred Adler: Theory and Application"). Common to inherency theorists is that conflict management should focus on the individual and not on group factors. Adler and his school specifically recommend re-education for those in crisis. Although Freud and Adler were never Christians and were not guided by religious opinions, their observations suggest that group and individual factors do influence church members in their actions and reactions and would therefore need to be considered in the search for any lasting management of conflict in the church. Erich Lindemann and Gerald Caplan significantly note that conflict makes people anxious, opens them to help, and motivates them to change (Moore, 2001, p. 161).

Coke (2008) underscores the importance of psychology to "conflict resolution." First, he notes that conflicts are becoming more common, complex, and destructive with no single approach appearing currently to be working effectively. Next, he points out that new questions that sometimes defy direct answers from the Bible and require the complementary views of other disciplines are being raised. Third, psychology is logically and inexorably linked to conflict resolution, but psychology is not equipped to deal with the spiritual aspect of the problem. Encouraging collaboration between psychological and church crisis management approaches which do not conflict with the principles regarded as sacred to the church therefore needs to be promoted. Coke makes four points that are most relevant to this work. The first is that conflict is different from disagreement because conflict involves negative emotions such as anger, fear, guilt, and shame. The second is that most conflicts take place beneath the surface, well below the superficial topics over which people are fighting and frequently hidden from their conscious awareness. The third is that conflict resolution skill can be developed by practice. Finally, Coke opines that debating values may not fully bring about resolution to conflict, but it has the potential of giving rise to a higher order of values.

Claudia (2003) recommends social psychology for the analysis of group conflict to complement whatever other analyses one uses. Claudia notes that history, perceptions, and identity are components of social psychological dimension to managing conflicts. The history of the conflict, and the progression that leads it to to the eruption of violence are important to its solution. The history would need to be acknowledged and the pattern formed noted. Then perceptions of the values of and threat from others, and of distribution of power would need to be analysed, and finally, identity the norms, beliefs, practices, and traditions with which one engages his or her environment. To social psychologists like Claudia, all sides to conflict resolution are fearful of compromise and it is important that all the sides 
recognize the fears and perceptions of others. But making compromise the only possibility of integrative effort is misleading. The two other possibilities are conciliation or victory for one party over the other (Akanji, 2011, p. 56; Tidwell, 1998, pp. 62-64).

Interactive problem-solving approach developed by Herbert C. Kelman has also been recommended for conflict resolution of long term crisis. It is a social-psychological method of intervention. This is an unofficial third party approach to conflict resolution between the unofficial representatives of conflicting parties, facilitated and moderated by someone knowledgeable on the process and on the history of the things involved. In it, the participants are encouraged to develop trust in face to face discussions. It operates in workshops to complement the work of the official representatives of warring parties. This approach is helpful where conflict has remained protracted and subjective rather than when objective factors are responsible (Demirdogen, 2011).

Schechner (1994, p. 626), a sociologist, following the theory of Victor Turner, locates conflict and its resolution in the context of dramaturgical model which consists of "four main phases of public action', which constitute 'the diachronic profile of social drama': (1) breach, (2) crisis, (3) 'redressive action,' and (4) reintegration or schism.” Turner's social dramas are public, symbolic scenes in which conflicts or disharmonies of society are played out (Eller, 2007, p. 129). The phrase of breach is when norms governing social relations within family, work-group, or other associations to which one belongs are violated. It becomes a crisis when it widens to become coextensive "with some dominant cleavage in the widest set of relevant social relations to which the conflicting or antagonistic parties belong” (Schechner, 1994, p. 626). It is advised that this phase should not be overlooked since crisis needs to be dealt with immediately. "Redressive action" is what is done to resolve the crisis, to end the conflict while reintegration is the elimination of the breach that engendered the crisis. Where reintegration fails, the problem either aggravates or schism results (Turner, 1974, pp. 23-59). Social dramas are therefore, performed processes of this social contest, played out in public and over a period of time from the initial breach in social relations, to a social crisis of some sort, to "redressive action" aimed at healing the breach, to the ultimate reintegration of actors into society and (ideally) the restoration of social relations and institutions (Eller, 2007, p. 129).

Commenting on effect of situations on which conflict management decisions are made, Messervey, Ji and, Uchida (2004, p. 361) note that tension can inhibit thorough search for alternatives and the exploration of new possibilities. While the selected psychological models identified above can be applied with caution to the church, it should be noted that the schools 
are directly or indirectly concerned with crisis management but not from the religious point of view. It is also important to note that willpower is insufficient to effect change, and the schools appear to ignore that human beings are basically selfish.

\section{Leadership in Church Crisis}

While "conflict" is generally regarded as a disagreement through which the parties perceive a threat to their needs, interests or concerns, crisis is a higher level of conflict which is a step from breaking parties involved apart. Krejcir points out that conflict is inevitable, "We will come across various disagreements, misunderstandings, and distinctions with various views of moral and value stands with one another that will converge in our relationships." Church history shows that conflict occurred at various times and when it did, the Church responded by re-examining and redefining its doctrines (Bragwell, 2012; Wallace). Apart from doctrinal crisis, members of local churches also encounter other types of crisis. Lawrenz, in an interview with the editors of Leadership Journal (2013), comments: "The church exists for times of crisis as much as it does for the easier parts of life. So it's critical for staff and key leaders to be ready for crisis before it happens." Crisis should however not be romantized. While crisis is preventable, or could be managed, at times it could be mismanaged. But times of crisis can be opportunities for the church to develop, if it handles its challenges well.

Conflict can escalate to crisis (Newberger, 2013). The first stage is when interpersonal relationship within the particular Christian society is preceded with uncomfortable feeling among members. At this stage, conflict potential only exists but needs the right condition for it to explode. The next stage is when an identifiable problem emerges. Here as they discuss the problem "The participants are civil and respectful to one another as they each share their perspective." As the focus of conversation changes from what should be done and what is the best solution, to a debate of who is right and who is wrong. Frustration sets in because the attempt to achieve one's goals is undermined by another. At this stage, parties need to be more cautious the way they deal with each other. If the matter is not resolved, then collaboration wanes except with those who take their respective side. When parties now see each other as adversaries and antagonists they tend to attack members of the other group verbally. Once conflict has escalated in intensity to certain level, direct discussion among parties involved has little usefulness. At this stage a neutral peacemaker is needed to resolve the differences.

While the current writers do not advise that theology be built on Acts of Apostles partly because it is a transitional book, they agree that one can still learn from the book. The story in Acts 6:1-7 reveals the way the early 
church dealt with the crisis caused by the treatment of the widows of the Grecian Jews. After a brief comment, the Apostles took three steps: Desensitizing the conflict by allowing widows to air their complaints; by deliberating on the conflict so that there was time for serious, mature discussion; and by making decision that certain people should handle the issue that caused the conflict (Dobbins, "Managing Church Conflict Creatively", n.d.). Leadership is actively involved in desensitization. In conflict management, however, leadership should not be employed to dominate but reassure everyone involved in the conflict that the encounter is normal in human relationship, and that the church is not immune to conflict. In deliberation, the leader/leadership team needs to consider the points of view of various people. Richard Dobbins, a counsellor and ordained minister of the Assemblies of God church in the USA suggests four guidelines for communicating in conflict situations. These are the need to use more of "I" than "You" statements; giving supportive feedback for people's willing responses; watching out for metacommunication from contributors; and flagging unnecessary provocative words. While "I" statements tend to be informative, "You" statements tend to be blaming. Metacommunication contains statements such as, "The Holy Spirit told me that ...," or "I perceived in my spirit that ....” They attempt to stop others from asking further questions and so stop further discussion on the issue concerned (Dobbins, “Managing Church Conflict Creatively”).

Contemporary Evangelicals are fairly accused of uncritically importing leadership models from "the corporate business world or from secular system of administration" because Christian leadership is not authority-driven (cf. Mark 10:35-45; cf. Bilezikian, 2007, p. 6). This criticism should however be taken with caution because both Christians and non-Christians benefit from general revelation through which God reveals certain truths to the whole humanity. St. Augustine rightly observes:

[...] let every good and true Christian understand that wherever truth may be found, it belongs to its master, and while he recognizes and acknowledges the truth even in their religious literature, let him reject the figments of superstition ("Quote of the Date”).

But Christian leadership has certain distinguishing features which include the presence of a gift of the Holy Spirit (Rom 12:8); and reliance on instruction, exhortation, and persuasion to fulfill its mandate (Bilezikian, 2007). Furthermore, church leadership in the New Testament is always plural:

There is no model in the New Testament for the one-pastor church. Local congregations are always led by teams selected from the congregation and accountable to it. Pastors are part of the leadership team and answerable to it. When recourse to 
authority becomes necessary, it is exercised by the leadership team. No individual leader may assume authority independently from the leadership team. The Apostle Paul was not a local pastor. Timothy and Titus were not pastors; they were temporary troubleshooters dispatched to selfdestructive congregations for the purpose of replacing corrupt leadership (Bilezikian, 2007, pp. 6-7).

In the New Testament, church leadership structures were flexible, and adaptable to local situations; and the effectiveness of church leadership team was not dependent upon the disposition of the heart of the leader rather than the administrative structure of the congregation: a hierarchical polity church may have servant-minded leaders, while a congregational polity church may be led by manipulative tyrants. In the New Testament, servant leadership shares leadership functions by developing potential replacement for itself (Bilezikian, 2007, p. 7). That was how Jesus approached administration with his disciples, and Paul approached it with Timothy and Titus. But prophetic leadership style appears to be the easiest and least effective to solve church conflict: It lays claim to direct solution from God to deal with church problem. One of its advantages is that it is rarely challenged by church members. Bilezikian (2007) notes,

A ... [reason] often adduced for strong, dominant individual leadership is the need for one person, presumably privileged with exceptional guidance from God, to engage in "visioncasting” for the group. The New Testament community model calls for such insights to be submitted to the scrutiny of the congregation. Rather than imposing one individual's visionary program on the body, genuine leadership requires this person to facilitate the vision to be formed at the congregational level in order to generate participation and ownership and to protect the church from rogue vagaries (p. 8).

It cannot be denied that prophetic insight has its role in solving church crisis especially where demonic involvement is present. But such prophetic vision cannot operate independently of the Bible. The revelation must still be tested by the truth of the Bible and examined by the body of Christ. An individual should not constitute himself to the authority that would solely dictate to the church not only because the gift can be abused but also because people can be manipulated by it. 


\section{Incorporating Vision into Christian Management of Crisis}

Peter O. Awojobi's (2003, pp. 43-44) interpretation of visionary leadership is different from the one adopted in this article. He links it loosely with "transformational leadership.” Awojobi (2003, p. 44) raises the following vital points for visionary leadership in times of crisis. First is that it is good to write down one's vision. Such actions removes doubt, reveals desires, exposes potential conflicts with the vision, and makes one accountable the way he/she acts. Second, the leader's vision should be communicated effectively through a clear and captivating presentation of the vision to members, repeated presentation of the vision, and evaluation of the communication efforts. Third, the leader should build support for the vision (Awojobi, pp. 44-46). These assume that the pastor's vision agrees with his church's vision, otherwise, conflict of vision is an invitation to conflict of interest and purpose.

In its effort to deal with conflict in the church, it is necessary the church continue to develop and maintain a sufficient number of crisis' managers (Cf. Mat 9:37-38). Reasons for this are multiple. There are various issues that call for attention in the church. As the church grows, so is the tendency for misunderstanding, increase in conflict, and rise in other potential threats to its oneness. Old age is making the replacement of some already serving in conflict management positions necessary. New challenges are arising for individual of and family members in the church and so the known approaches to crisis management would need to be re-evaluated. The goals, purposes, or emphases of the church may need to be changed and changes in crisis management would need to reflect these.

\section{Dealing with Trouble Makers in the Church}

The discussions following integrate psychological with theological insights. Every church has its own trouble makers who do not necessarily have emotional problems but they are irksome. They become a threat to the health of the mainstream of the church as they struggle to control the church. According to Dale (1985),

Difficult people fall into two broad categories: aggressive and passives. Aggressive controllers include hostile persons, cliques, and non-communicating 'crazymakers.' Passive controllers count in their numbers apathetic persons, lonely people, and traditionalists. Aggresives try to dominate the agenda of their congregations; passives place a drag on the mission and momentum of their congregations (pp. 76-77).

Caldwell (1985) also adds that "A church would do well to establish a procedure for dealing with disputes, disagreements, or grievances which are bound to develop in spite of the best of Christian intentions. It is tragic 
when such disputes make it to the court system to be resolved. Every effort should be made to settle such matters within the framework of the church structure” (p. 233). To prevent such (Cf. 1 Cor 6:1) the church should make provision to deal with internal problems before they get out of hand. There are various ways to deal with difficult people. Dale (1985, p. 77) suggests a five-step approach: Identifying the cause of the conflict; rating the relationship between the parties involved in the tension and the church leaders; counting the costs of negative behavior of those involved on the congregation; searching for opinions available for dealing with the problem; and leading members of the parties to advancing towards the ultimate mission of the congregation.

It has been suggested that there are five types of conflict ministers. The first type is called the problem solver "... who works within conflict to bring forth the best possible conclusion for all of the parties engaged in the friction. Such a person is unafraid of sharp expressions of opinions and is willing to keep pressing for conversation and negotiation when others would give up” (McSwain \& Treadwell, 1981, p. 171). This type of approach has its strengths and weaknesses. The advantage of problem solving approach is that it is not afraid of conflict. One of its weaknesses is that it does not lend itself to some conflict situations such as with high explosive emotional issues. The second style of conflict minister is the super helper. "This is the person who is constantly working to help others with little concern for self" (McSwain \& Treadwell, 1981, p. 173). Next is the power broker "who uses the power available to achieve his or her goals in a specific situation. The power broker is committed to win a position, an issue, an argument, or a dream” (McSwain \& Treadwell, 1981, p. 175). His or her primary concern is to achieve personal goals. He is not concerned with personal relationships. The fourth style of conflict minister is the facilitator. "This person is highly adaptive to a variety of situations and styles. ... [He] is one who does not function from a primary style, but shifts from style to style, depending upon the situation. The primary method of the facilitator is to seek a compromise between competing factions” (McSwain \& Treadwell, 1981, p. 177). The last type of conflict minister mentioned by McSwain and Treadwell (1981) is the fearful loser. It is a style of passivity/withdrawal. "Such a person does everything possible to avoid engagement with conflict” (p. 179) Elijah's contest with the priests of Baal was an example of this. The concern of the power broker is the achievement. The most helpful process known to the present writer is suggested by McSwain and Treadwell.

The five steps below are recommended for conflict management in the church. The first step is to be sensitive to potential for conflict. This potential can be in the assumptions held and the context of conflict. The second is avoiding conflict with integrity. One can ignore the situation with 
the intention of avoiding it or face it squarely. The third is to engage the conflict events productively. Dealing with the conflict that has surfaced publicly begins with this third step. "Conflict can be diffused by delaying discussion, decision, or attempted resolution until a longer time has been spent in analyzing the conflict” (McSwain \& Treadwell, 1981, p. 44). Once unexpected conflict has been diffused, the process of problem management begins. The fourth step is the conclusion of conflict through responsible decision making. The conflict minister is most visible at this stage. "Briefly, the responsibilities of the conflict minister at this step of the process are as follows:

1. State clearly the purposes of the meeting and the nature of the decisions to be made.

2. Outline the ground rules which are to be followed in the course of decision making.

3. Be sensitive to the emotional reactions of the group to the decision making process.

4. Engage the emotion exhibited at various levels.

5. Refuse to play engagement games to influence the decision.

6. Give the group freedom to decide (McSwain \& Treadwell, 1981, pp. 45-46).

The fifth step is celebrating the success of conflict management. No conflict can be fully solved. For some people, in most situations, conflict resolution would leave some negative consequences especially where one party feels that it has defeated the other. In every situation, attempts should be made to bring about the glory of God in resolving conflict.

\section{Conclusion}

As good as servant-leadership is for Christianity (Cf. John 13:2-15), it is always an overstatement to say that it is the only acceptable leadership style, and that it is "right" in all situations (Smith, 1999, p. 78). Eclectic theories of crisis management convincingly suggest that a combination of approaches would work better than a single approach. Better still, the method that works in a particular situation may not work in another situation due to differences in the factors involved. Sensitivity and flexibility are necessary watchwords while dealing with crisis situations between and among church members. A few years ago, a new concept called "Life giving leadership style” was developed although there is no consensus on its meaning. According to Powers (1979) "a life-giving leadership style” defies all traditional concepts of leadership:

It is ... eclectic in style, since a life-giving leader may at times appear authoritarian, and at other times, overtly democratic. The life-giving leader is a person for all seasons, adjusting as the demand of a situation 
change. However, while leadership techniques and methods may vary, there is much beneath the surface that is unchanging (p. 11).

This life-giving leadership that Powers (1979) regarded as "a new concept of leadership" is flexible; and is committed to church ministry by identifying and serving the needs of members (Cf. Matt 20:26) by helping members become what they are intended to be under God (Cf. Eph 4:13). It is also committed to helping members individually develop their relationship with God and with one another. All these make life-giving leadership relevant to the problem of conflict and crisis which may be destructive to the church of God.

At this point, it is necessary to remember that not all church problems result from leadership failure. Bursch (2013) is strangely right, "there is one big giant problem with ... 'blame the leader' model ...: It's not biblical! The Scripture is full of rebellions occurring in the face of excellent leadership." In fact, it is doubtful if any leader - Christian and non-Christian - ever successfully handled all problems at all times. While some of Bursch's biblical examples are contestable, others are convincing.

The contention of this article is that the church will be more effective in dealing with crisis within it if it appropriates insights from other disciplines where they do not conflict with the Bible. The church will do well to complement whatever other conflict management methods it uses for prolonged crisis with Kelman's interactive problem-solving approach to reduce the subjective factors promoting it. Education in God's word and solicitation for God's help in prayer cannot be divorced from any Christian solution to crisis.

\section{References:}

About Conflict. No date. From http://www.ohrd.wisc.edu/onlinetraining/resolution/aboutwhatisit.html.

Adams, Jay E. 1986. Competent to Counsel. Grand Rapids: Zondervan.

Akanji, Israel A. 2011. Towards a Theology of Conflict Transformation: A Study of Religious Conflict in Contemporary Nigerian Society. A PhD dissertation submitted to The University of Edinburgh.

Alfred Adler: Theory and Application. Alder Graduate School. No date. From http://www.alfredadler.edu/about/theory.

Are You Ready for a Crisis? Leadership Journal. 2013. From http://www.christianitytoday.com/le/2013/february-online-only/are-youready-for-crisis.html.

Augustine, St. No date. On Christian Doctrine. Book II. From http://faculty.georgetown.edu/jod/augustine/ddc.html.

Awojobi, Peter O. 2003. Church Management. Ilorin: Kingdom. 
Bilezikian, Gilbert. 2007. Church Leadership that Kills Community. Priscilla Papers, 21:4, pp. 5-7..

Bragwell, Edward O. 2012. The Church in Crisis. The Auburn Beacon. From http://www.aubeacon.com/Articles2012/Article_TheChurchInCrisis.html.

Bursch, Doug. 2013. Sometimes Rebellion is the Fruit of God Leadership, 30. From http://fairlyspiritual.org/2013/10/30/sometimes-rebellion-is-thefruit-of-god-leadership-a-must-read-for-pastors/.

Caldwell, William G. 1985. Legal Matters. Church Administration Handbook. Edited by Bruce B. Powers. Nashville: Broadman, pp. 230-242.

Calvin, John. No date. Calvin's Commentary: Timothy, Titus, and Philemon, vol. 43. Translated by John King (1847-50). From http://www.sacredtexts.com/chr/calvin/cc43/cc43020.htm.

Church Management: Combining the Spiritual and the Orgaizational. No date. From http://business.baylor.edu/phil_vanauken/cmanage.htm.

Claudia, Seymour. 2003. Social Psychological Dimensions of Conflict. Beyond Intractability. Edited by Guy Burgess \& Heidi Burgess. From http: www.beyondintractability.org/essay/social-psychological.

Coke, Kenneth. 2008. Building Bridges between Psychology and Conflict Resolution - Implications for Mediator Learning. Mediate.Com. From http://www.mediate.com/articles/cloke7.cfm.

Conflict Management: No date. Psychology and Science. International Association of Business and Management Professionals.". From http://iabmp.org/conflict-management-psychology-and-science/.

Dale, Robert D. 1985. Working with People. Church Administration Handbook. Edited by Bruce P. Powers. Nashville, Tennessee: Broadman, pp. 66-80.

Defining Christian Leadership. No date. Christian Leadership Center, Andrews University. From http://old.andrews.edu/clc/christianleadership.html.

Demirdogen, Ulku D. 2011. A Socio-Psychological Approach to Conflict Resolution: Interactive Problem Solving. International Journal of Social Inquiry, 4, 1: 215-226.

Dobbins, Gaines S. 1968. Learning to Lead. Nashville: Broadman.

Dobbins, Richard D. No date. Managing Church Conflict Creatively. From http://ag.org/top/church_workers/intper_gen_conflictmang.cfm.

Eller, Jack David. 2007. Introducing Anthropology of Religion: Culture to the Ultimate. New York: Routledge.

Flashing, Sarah J. 2011. All Truth is God's truth - So? First Things.. From http://www.firstthings.com/blogs/firstthoughts/2011/07/all-truth-is-godstruth-so. 
Folarin, George O., Adelakun, Adewale J. \& Folarin, Comfort O. 2015. Managing Conflict among Disciples (Luke 17:1-10) in the Nigerian Church Context. Journal of Oriental and African Studies, 24, 288-302.

Hicks, Donald D. 2010. A Study of the Conflicts within Churches that Lead to the Termination of Pastors within the Southern Baptist Convention, accompanied by a Proposal of Preventive and Interventional Solutions. A D.Min thesis submitted to Liberty Baptist Theological Seminary, Lynchburg, Virginia.

Introduction to Psychology and Counselling: Christian Perspectives and Applications. 1982. Edited by Paul D. Meier, Frank B. Minirth \& Frank B. Wichern. Grand Rapids: Baker.

Kieh, George Klay. 2002. Theories of Conflict Resolution, in Zones of Conflict in Africa: Theories and Cases. Edited by George Klay Keih, \& Mukennge, Ida Rousseau. Westport: Praeger Publishers, pp. 9-20.

Krejcir, Richard J. No date. Cultivating Effective Biblical Solutions for Conflict. The Francis A. Schaeffer Institute of Church Leadership Development.

From

http://www.churchleadership.org/pages.asp?pageid=66928.

Kulikovsky, Andrew S. No date. Scripture and General Revelation. From http://creation.com/scripture-and-general-revelation.

LaHaye, Tim. 1994. Spirit-Controlled Temperament. Revised edition. Wheaton: Tyndale House.

LaHaye, Tim. 1971. Transformed Temperaments. Wheaton: Tyndale House.

LaHaye, Tim. 1984. Your Temperament: Discover Its Potential. Wheaton: Tyndale House.

Leadership Surveys Church Conflict. 2004. From http://www.christianitytoday.com/le/2004/fall/6.25.html.

Mathison, Keith. 2011. All Truth is God's Truth — A Reformed Approach to Science and Scripture. From http://www.ligonier.org/blog/all-truth-godstruth-reformed-approach-science-and-scripture/.

Mathison, Keith. 2012. Interpreting General and Special Revelation - A Reformed Approach to Science and Scripture. From http://www.ligonier.org/blog/interpreting-general-and-special-revelationreformed-approach-science-and-scripture/.

Mathison, Keith. 2012. When Science and Scripture Conflict - A Reformed Approach to Science and Scripture. From http://www.ligonier.org/blog/when-science-and-scripture-conflict-reformedapproach-science-and-scripture/.

McSwain , Larry L. \& Treadwell, William C. 1981. Preface. Conflict Ministry in the Church. Nashville: Broadman. 
Messervey, Deanna, Ji, Li-Lun \& Uchida, Yukiko. 2004. Cognition and Culture. Encyclopedia of Applied Psychology. Edited by Charles Spielberger. Elservier: Academic Press, pp. 357-363.

Moore, Timothy. 2001. Crisis Intervention. Gale Encyclopaedia of Psychology. Second edition. Edited by Bonnie B. Strickland. Michigan: Gale, pp. 160-161..

Nattan, Steve Van. No date. R.C. Sproul: Raging Heretic and Blasphemer. Blessed Quietness Journal. From http://www.blessedquietness.com/journal/resource/rcsproul.htm.

Newberger, Ken. 2013. Institute of Reconciliation and Peacemaker Training. From

http://www.resolvechurchconflict.com/the_stages_of_unresolved_church_co nflict.html.

Oyeniyi, Oluseye David. 2014. The Principles of Reconciliation in Matthew 18:15-35 and its Implications for Conflict resolution in CAC in Osun State. M.A. Thesis submitted to the Postgraduate College, Obafemi Awolowo University, Ile-Ife.

Pearce, Cindi. No date. Differences between a Conflict and a Disagreement. eHow, University of Liverpool. From http://www.ehow.com/info_8218226_differences-between-conflictdisagreement.html.

Peters, Kay L. 2010. Conflict Management in the Christian Church. A research paper presented to the Faculty, Adler Graduate School, Richfield, Minnesota, for the degree of M.A. in Counselling and Psychology.

Powers, Bruce P. 1979. Christian Leadership. Nashville, Tennessee: Broadman.

Psychology is the Devil: A Critique of Jay Adam's Counselling Paradigm. 2007. From http://theophilogue.com/2007/09/28/psychology-is-the-devil-acritique-of-jay-adams-counseling-paradigm/.

Quote of the Date: Augustine - Wherever Truth may be Found it belongs to the Lord. No date. Café Apocalypsis, From http://alanbandy.com/?p=230.

Ramm, Bernard. 1967. Christian View of Science and Scripture. Exeter: Paternoster.

R.C. Sproul Responds. No date. From http://www.rapidnet.com/ jbeard/bdm/exposes/sproul/respd.htm.

Roberts, Barbara. 2012. Abuse and Nouthetic Counselling: A Firsthand Analysis of the Harm it does. From https://cryingoutforjustice.com/2012/10/02/abuse-and-nouthetic-counselinga-firsthand-analysis-of-the-harm-it-does/.

Rothbart, Mary K., Ahadi, Stephen A. \& Evans, David E. 2000. Temperament and Personality. Journal of Personality and Social Psychology, 78/1, 122-135. 
Schechner, Richard. 1994. Ritual and Performance. Companion Encyclopedia of Anthropology. Edited by Tim Ingold. London: Routledge, pp. 613-647.,.

Tim and Beverly LaHaye Exposed. No date. From http://jesus-issavior.com/Wolves/tim_and_beverly_lahaye_exposed.htm.

Turner, Victor. 1974. Dramas, Fields and Metaphors. Ithaca, NY: Cornell University Press.

Wallace, Daniel B. No date. The Church in Crisis: A Postmodern Reader. $O$ Bible Org. From https://bible.org/article/church-crisis-postmodern-reader.

Yurica, Kathrine. 2007. Tim LaHaye and Temperament Theory. Yurica Report.

From

http://www.yuricareport.com/RevisitedBks/TimLaHayeDivinator.html. No date. 